\title{
Transaction-Cost-Based Selection of Appropriate General Contractor-Subcontractor Relationship Type
}

\author{
Hyun-soo Lee ${ }^{1}$; Joon-oh Seo, M.S. ${ }^{2}$; Moonseo Park, M.ASCE${ }^{3}$; Han-guk Ryu, Ph.D. ${ }^{4}$; and \\ Soon-seok Kwon ${ }^{5}$
}

\begin{abstract}
Relationships between general contractors and subcontractors are generally formed on a project-by-project basis. However, because of the competitive nature of the construction industry, this traditional arrangement can result in adversarial relationships between general contractors and subcontractors, which can jeopardize potential or ongoing collaborative construction plans. To avoid this problem, close, long-term relationships between general contractors and subcontractors, as in strategic partnerships, must be established. Unfortunately, forming and sustaining such relationships can be time-consuming and cost-intensive. Furthermore, this type of relationship does not necessarily enhance cooperation or work performance. For contractors to successfully establish effective partnerships with their subcontractors, they must select the appropriate relationship by considering the different characteristics of the subcontracted work involved. Based on transaction cost theory, the findings of this study show that transaction costs incurred by general contractors and subcontractors vary according to the type of relationship established. Therefore, for the purpose of comparing transaction costs incurred in both competitive and partnership relationships, transaction-cost-based profit models for both general contractors and subcontractors are developed, respectively, for each relationship type. As well, by applying different strategies to maximize profits in each relationship, and by simulating the parameters affecting the nature of the subcontracted work, the conditions and relationships under which general contractors' profits are optimized have been determined. Finally, based on simulation, practical guidelines for choosing the most appropriate relationship type are proposed.
\end{abstract}

DOI: 10.1061/(ASCE)CO.1943-7862.0000086

CE Database subject headings: Subcontracting; Costs; Theories; Profits; Construction industry.

\section{Introduction}

Approximately $80-90 \%$ of construction work is performed by subcontractors (Hinze and Tracy 1994). This dependency on subcontractors highlights the need for general contractors to effectively and efficiently manage subcontractors in various trades. However, competitive relationships between general contractors and subcontractors that result in adversarial and win-lose situations can hinder or even prohibit the establishment of collaborative relationships. In order to overcome and avoid the problems

${ }^{1}$ Professor, Dept. of Architecture, Seoul National Univ., 39-430, San 56-1 Shinlim-dong, Kwanak-gu, Seoul 151-742, Korea. E-mail: hyunslee@snu.ac.kr

${ }^{2}$ Researcher, Construction Strategic Research Institute, Hanmiparsons Co. Ltd., 9th Fl., City Air Tower Bldg. 159-9, Samsung-dong, Kangnangu, Seoul 135-090, Korea. E-mail: cico81@ naver.com

${ }^{3}$ Associate Professor, Dept. of Architecture, Seoul National Univ., 39-433, San 56-1 Shinlim-dong, Kwanak-gu, Seoul 151-742, Korea (corresponding author).E-mail: mspark@snu.ac.kr

${ }^{4}$ Full-Time Lecturer, Dept. of Architectural Engineering, Changwon National Univ., 9 Sarim-dong, Changwon, Gyeongnam 641-773, Korea. E-mail: hgryu@changwon.ac.kr

${ }^{5}$ M.S. Course, Dept. of Architecture, Seoul National Univ., 39-433, San 56-1 Shinlim-dong, Kwanak-gu, Seoul 151-742, Korea. E-mail: dreamkss1@snu.ac.kr

Note. This manuscript was submitted on March 5, 2008; approved on May 6, 2009; published online on May 8, 2009. Discussion period open until April 1, 2010; separate discussions must be submitted for individual papers. This paper is part of the Journal of Construction Engineering and Management, Vol. 135, No. 11, November 1, 2009. (CASCE, ISSN 0733-9364/2009/11-1232-1240/\$25.00. associated with competitive relationships, Korean construction firms have attempted to establish long-term interorganizational relationships with key subcontractors through arrangements such as strategic partnerships or strategic alliances.

Previous studies (Kumaraswamy and Matthews 2000; Zou and Lim 2005; Dainty et al. 2001) have already recognized this trend and have stressed the need for contractors to improve their relationships with subcontractors. However, these studies have also overlooked the shortcomings of such relationships. Indeed, building a closer relationship with all subcontractors can be timeconsuming, costly, and does not necessarily ensure better work performance. Bensaou (1999), for instance, has argued that to achieve successful supplier-relationship management, supplier portfolio management, which emphasizes the adoption of a relationship type based on a particular project or market condition, is necessary alongside proper management practices. Yet, the argument for choosing appropriate relationships with subcontractors based on project characteristics has yet to be widely researched with regards to the construction industry.

Based on the transaction cost approach, this study attempts to address this issue by identifying the key factors that indicate strategic partnerships with subcontractors can be applied. As well, the particular conditions that make construction projects suitable for strategic partnerships have been investigated, and competitive and alternative relationships have been compared through a literature review. Furthermore, by applying transaction cost theory (Williamson 1989), how transaction costs precisely influence relationship type selection has been examined. Based on the research findings, two theoretical profit models have been developed by modifying the model by Richardson and Roumasset (1995); these 
models are respectively constructed for the competitive relationship and strategic partnership between general contractors and subcontractors. Additionally, after simulating the models using the relative values of parameters which indirectly reflect subcontracted work conditions, a set of considerations for selecting appropriate contractor-subcontractor relationships at the corporate level are identified. These guidelines can potentially assist construction firms in strategically and effectively managing subcontractors so that project performance is enhanced.

\section{Subcontractor-Relationship Types}

\section{Competitive Relationships}

In competitive relationships, which are also referred to as distributive, win-lose, or adversarial relationships, supply-chain members act out of self interest to acquire a larger share of a project (Trent 2005). Despite negative characteristics, competitive relationships have been preferred in the construction industry. Because contractor-subcontractor relationships are generally formed on a project-to-project basis, many uncertainties arise during construction due to demand fluctuation, rapid changes in customer preferences, project-specific component activities, technological advances, and seasonality. Therefore, given these industryspecific characteristics, competitive contractor-subcontractor relationships have been used to transfer the associated risks to other project participants (Usdiken et al. 1988).

Furthermore, competitive bidding and price comparison strengthens competitive relationships between general contractors and subcontractors. Although most subcontractors consider the competitive bidding process to be fair, head-to-head competition among potential subcontractors diminishes their bargaining power with general contractors. Because subcontractors have the greatest potential for cost savings, general contractors adopt the competitive bidding process to maximize their own bargaining power. However, this often results in unfair contractual conditions and onerous practices (Kumaraswamy and Matthews 2000).

\section{Alternative Relationships}

Recently, the construction industry has recognized that project success is heavily dependent on the contractor-subcontractor relationship. Consequently, the industry has come to focus on interorganizational coordination between general contractors and subcontractors, and various concepts designed to improve this relationship have emerged from the experiences of different construction firms. In this section, two alternative relationships, strategic partnering and strategic partnership, will be discussed with a particular focus on their effectiveness at the project level and corporate level.

\section{Strategic Partnering}

In strategic partnering, subcontractors undertake more than one construction project or several construction activities at any point in time. Partnering was first proposed by the Latham Report (Latham 1994), which aimed to improve interactions between clients and main contractors through the formation of partnerships and strategic alliances (Dainty et al. 2001). There are many definitions of "partnering." One of the most commonly used definitions characterizes partnering as "a long-term commitment between two or more organizations for the purpose of achieving specific business objectives by maximizing the effectiveness of each participant's resources" (Kumaraswamy and Matthews 2000). Although research on partnering has focused mainly on the client-main contractor relationship, it has also been argued that partnering with key subcontractors can help improve the main contractor-subcontractor relationship (Kumaraswamy and Matthews 2000; Dainty et al. 2001; Shimizu and Cardoso 2002; Kim and Kim 2003). Partnering that involves a high level of interorganizational trust and dedication to common, beneficial goals, is an alternative strategy that firms can deploy to achieve a competitive advantage.

\section{Strategic Partnership}

Throughout the years, business and academic journals have argued that managers need to replace arm's length relationships with longer-term, collaborative, and strategic partnerships with external business partners (Bensaou 1999). Strategic partnerships are particularly effective when the parties involved are committed, willing to cooperate, and share resources in the pursuit of common goals.

However, while strategic partnerships are often used in the automotive industry, only a single instance in which the concept is used by a Korean construction company was found. This company has attempted to apply strategic partnership with subcontractors by benchmarking the practice in the automotive industry. In this company, subcontractors are strategic partners involved in the planning phases of construction, which facilitates the application of their experience and specialized knowledge.

Furthermore, commitment to continuous subcontracted projects enables subcontractors to gain more profits from economies of scale. For example, finishing work subcontractors who install curtain walls can accurately estimate future demand and thus reduce costs by purchasing materials in a more timely manner. Cost reduction by subcontractors subsequently leads to a decrease in unit price. Also, in the context of a continuous subcontracted project, general contractors are given the opportunity to provide partnering subcontractors with training or managerial support.

Indeed, there are many common features between strategic partnerships and strategic partnering, and with the existing problems in current subcontracting practice, both strategies are recommended to improve relationships with subcontractors. As well, both approaches ultimately highlight the need for close and longterm relationships between contractors and subcontractors. In more intimate contractor-subcontractor relationships, the problems found in competitive relationships, such as a lack of coordination, can be overcome, and the knowledge and experience gained through a sustained relationship can enhance cooperation and future collaboration. For example, in strategic partnerships, general contractors can help develop subcontractors' abilities by providing training or technical and managerial support if necessary. As a result, general contractors and subcontractors are able to foster a relationship built on trust, which results in a productive, win-win relationship. As these two alternative relationship types share similar features, to unify the terminologies, strategic partnerships and strategic partnering will be referred to as "strategic partnerships" from now on in this paper.

\section{Selection of an Appropriate Transaction-Cost-Based Relationship}

However, despite potential advantages, there have been practical obstacles to adopting strategic partnerships. First, establishing a 
Table 1. Assumptions and Variables in TCE

\begin{tabular}{|c|c|c|}
\hline & Factor & Illustration \\
\hline \multirow[t]{2}{*}{ Assumption } & Bounded rationality & $\begin{array}{l}\text { - Bounded rationality refers to the fact that people have limited memory and limited } \\
\text { cognitive processing power. No matter how knowledgeable managers might be, they } \\
\text { cannot consider all the possible alternative courses of action. }\end{array}$ \\
\hline & Opportunism & $\begin{array}{l}\text { - Opportunism occurs when people act in a self-interested way and "with guile." That is, } \\
\text { people may not be entirely honest about their intentions, or they might exploit another } \\
\text { party by taking advantage of unforeseen circumstances. }\end{array}$ \\
\hline \multirow[t]{3}{*}{ Variables } & Frequency & $\begin{array}{l}\text { - Frequency indicates whether transactions are frequent or rare. If firms use certain } \\
\text { services frequently, they may decide to set up an in-house operation. }\end{array}$ \\
\hline & Uncertainty & $\begin{array}{l}\text { - Occurs because of the difficulty of predicting what might occur during the course of a } \\
\text { transaction. Uncertainty causes problems, in part, because of bounded rationality, } \\
\text { information asymmetries, and the dangers of opportunism. }\end{array}$ \\
\hline & Asset specificity & $\begin{array}{l}\text { - Investments in transaction-specific assets improve the efficiency of some transactions. } \\
\text { However, the party that has not invested may expropriate some of the value of the } \\
\text { investment by threatening to walk away from the relationship. }\end{array}$ \\
\hline
\end{tabular}

strategic partnership is a time-consuming and expensive process. Furthermore, there still exists doubt that strategic partnerships are superior to traditional forms of subcontracting. For a strategic partnership to function efficiently, continuous coordination is required, especially prior to project commencement. As well, the training programs and financial support required to develop strategic partnerships incur additional costs for general contractors. More important, general contractors can lose opportunities gained through competitive subcontracting, as their strategic partners are contracted to conduct continuous work.

For these reasons, general contractors should consider subcontractor-relationship management which entails treating their subcontractors differently and discarding "one-size-fits-all" strategies for subcontractor management (Dyer et al. 1998). As well, contractors must consider the pros and cons of competitive relationships and strategic partnerships before selecting the most appropriate contractor-subcontractor relationship type, one that maximizes the advantageous features of competitive or partnership relationships.

\section{Transaction Cost}

Basically, general contractors' profits are determined by the price of contracts with subcontractors and project owners. Additionally, management efforts to guarantee the quality of subcontracted work and to finish the project by the completion date incur additional costs. As well, unexpected factors that arise during a project can result in cost overruns which reduce general contractors' profits. These variable costs are called "transaction costs." The term "transaction" refers to the transferring of resources such as materials or services (Kale and Arditi 2001). When transactions occur within an organization, the transaction cost includes the managing and monitoring of personnel, as well as the procuring of inputs and capital equipment. On the other hand, the transaction costs associated with buying goods and services from an external provider include the costs of source selection, contract management, performance measurement, and dispute resolution (Pint and Baldwin 1997).

\section{Transaction Cost Economics in Construction Subcontracting}

Transaction cost economics (TCE) is considered to be the most influential attempt to apply an economic theory to the structure of firms (Williamson 1989). Based on bounded rationality and op- portunism in human behavior, the transaction cost approach characterizes the transactional environment according to uncertainty, frequency of transactions, and relation-specific assets (Table 1). The TCE approach can be used to understand subcontractors' attempts to increase their profits as well as general contractors' strategies to reduce transaction costs and improve construction performance.

As previously discussed, contractor-subcontractor relationship types can be classified according to asset specificity and the continuity of relationship, as depicted in Fig. 1. Asset specificity is commonly defined as the extent to which the investments made to support a particular transaction have a higher value than they would have if redeployed for any other purpose. In some cases, general contractors guarantee their subcontractor partners continuous work and invest in a closer relationship with these subcontractors by providing training and even managerial support. These kinds of investments are valuable only so long as they maintain the partnership relationship. Therefore, the partnership relationship is highly asset-specific.

In construction projects with high degrees of uncertainty, there is a greater potential for subcontractors to demonstrate opportunistic behavior, such as lowering the quality of the subcontracted work by reducing resource input in order to maximize their profits. However, due to the bounded rationality of general contractors, this behavior is rarely detected even though such opportunism incurs additional costs to the subcontractor known as shirking costs (Richardson and Roumasset 1995). For example, the cost of rework, due to low quality of subcontracted work, is a

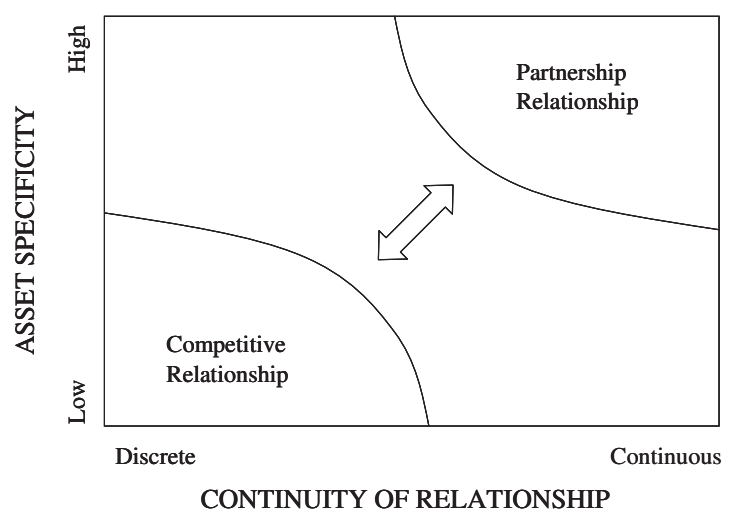

Fig. 1. Classification of relationship types 
type of shirking cost. In a competitive relationship, general contractors generally assume that subcontractors will deliver the utmost performance and abstain from opportunistic behavior, as dissatisfying the general contractor could result in the loss of future business. On the other hand, in strategic partnerships, although this relationship type has various advantages, it is sometimes difficult for general contractors to forestall subcontractors' opportunistic behavior, particularly when transaction-specific investment is involved.

However, despite this disadvantage, there are several specific reasons why partnerships are an effective relationship type: (1) subcontractor involvement in the planning phases of construction can reduce uncertainty during construction projects; (2) the collaborative nature of partnerships and the information sharing involved in this relationship type complement the bounded rationality of general contractors; and (3) in a trust-based relationship, the cynicism associated with opportunistic behavior tends to be minimized.

Nevertheless, if transaction-specific investment is involved that supports the development of subcontractors' skills and knowledge, these benefits can be reversed. As mentioned in Table 1 , asymmetry in transaction-specific investment can provoke noninvesting subcontractors to expropriate some value of the investment by threatening to walk away from the relationship. Furthermore, in the construction industry, subcontractors have a higher transferability of relation-specific assets than general contractors. Thus, when a relationship ends, the subcontractors' enhanced capability enables them to secure business with new general contractors. As a result, general contractors must pay additional costs to establish new relationships with other subcontractors. The cost related to this phenomenon is known as the "switching cost." If subcontractors recognize that the switching cost of the general contractor exceeds the cost incurred by their own low performance, they can maintain this low performance and increase their profits without worrying about general contractors "switching" (Richardson and Roumasset 1995).

For this reason, general contractors generally prefer competitive contractor-subcontractor relationships and hesitate to invest in their subcontractors, as such investments increase asset specificity between relationships, which consequently causes switching costs to be incurred. This suggests that in strategic partnerships which involve relation-specific assets that incur switching costs to the general contractor, general contractors must minimize subcontractors' opportunistic behavior which is motivated by switching costs. General contractors can do this by enhancing monitoring mechanisms.

Further, despite the evident differences between competitive and strategic partnership relationships, construction firms find it difficult to decide which type will be most beneficial, as the advantages and disadvantages of each type vary according to specific transactional situations and conditions. It is also challenging to measure costs associated with the different governance structures of various transactions; thus, it is hard to determine how these costs influence the total project cost. To address this, profit models were developed that can be used to measure, on a theoretical basis, the transaction costs of both the general contractor and subcontractors in a competitive and partnership relationship, respectively.

\section{Model Development}

When transacting with subcontractors, the main concern of construction firms is to maximize their profits by reducing the total cost (which includes production and transaction costs). Thus, in this study, two profit models-the competitive model and partnership model-were developed to compare the costs involved in competitive relationships and strategic partnerships. The means through which the general contractor's profit is maximized with the proper subcontractor-relationship type were determined for various conditions. The models were constructed by adapting the model of Richardson and Roumasset (1995) for the construction industry.

The profit models were designed to present the general contractor's profit from only one subcontracted work with fixed quantities of work in a project, not the total profit of the project. In the models, the type of contract used for the work is a unitprice contract. Although this type of contract is based on the estimated quantities and unit prices of the various items included in the project, to design a simplified model, it is assumed that only one type of item is used in the work. According to the contractor-subcontractor relationship type, the profit models have different parameters which reflect various project and subcontracted work conditions. Detailed descriptions of the models are as follows.

\section{Competitive Model}

The general contractor's profit function incorporates the value that can be obtained from the subcontracted work as well as the cost of that work. The value that the general contractor can obtain from the work increases in proportion to the quantity of the work, and it can be transferred as profit. Profit is reduced, of course, if the cost increases. The cost consists of the production cost, which is the subcontractor's bidding price, and the transaction cost. In the approach by Richardson and Roumasset (1995), transaction costs include shirking cost, management cost, and coordination cost. The overall profit function for a general contractor, then, can be formulated as follows:

$$
\begin{gathered}
\Pi_{G}^{\mathrm{com}}=V(q)-C(c, S, M, K) \\
V(q)=v q \\
C(c, S, M, K)=c q+S(P, q)+M(i, q)+K(a, q)
\end{gathered}
$$

where $V(q)=$ value from the subcontracted work; $v=$ general contractor's unit value from one component; $q=$ quantity of subcontracted work; $C(c, S, M, K)=$ general contractor's total cost; $c=$ contracting unit cost; $S(P, q)=$ shirking costs; $P$ =subcontractor's performance; $M(i, q)=$ management cost; $i$ =inspection level; $K(a, q)=$ coordination cost; and $a$ $=$ coordination level.

\section{Value from the Subcontracted Work: $V(q)=v q$}

The general contractor's value $V(q)$ increases as the quantity of subcontracted work increases because the average value from one component of the work is fixed. For clarity in analysis, the quantities are used to indicate only the total volume of the subcontracted work.

\section{Production Cost: $c q$}

Although methods of paying subcontractors can vary, in the model, contracts with subcontractors are assumed to be unit-price contracts. The variable $c$ represents the unit cost per one component. 


\section{Shirking Cost: $S(P, q)=[h(1-P) / P] q$}

The shirking cost is incurred by the general contractor as a result of the subcontractor's poor performance. This cost increases if the performance level of the subcontractor decreases. The parameter $h$ indicates the cost incurred due to poor performance.

\section{Management Cost: $M(i, q)=\alpha m\left(i_{0}+i\right) q$}

Management cost is required to ensure the expected performance level. Inspection level $(i)$ is the proportion of inspected work to subcontracted work. The parameter $m$ represents the inspection cost for the subcontracted work. The management tasks of the general contractor commonly include all of those performed by the subcontractor. Accordingly, the general contractor's management task workload can be determined, which is in turn used to determine management cost. To reflect this, the parameter $\alpha$, which signifies the proportion of labor to the total amount of subcontracted work, is added. The parameter $i_{0}$ represents the minimum inspection level.

\section{Overall Coordination Cost: $K(a, q)=(1-s) k a q$}

Due to the high level of uncertainty in construction projects, the general contractor may focus on coordination with subcontractors. Coordinating subcontractors' work is one of the most complex tasks in construction. The variable $a$ represents the coordination level desired by the general contractor. Coordinating with subcontractors requires that general contractors input their resources, which include time, materials, and even labor. All of these factors influence the general contractor's costs. Coordination cost $k$ is the cost required to coordinate with a certain subcontractor. However, the coordination cost can be reduced if the subcontracted work is standardized, as there is less uncertainty in standardized work than in customized work. The parameter $s$ represents the standardization level of the subcontracted work.

Meanwhile, the subcontractor's profit function consists of the contracting cost in the form of the bid offered, as well as costs to ensure the expected performance level. When the subcontractor's work is so poor that the general contractor demands that the performed work be redone, rework cost is incurred (Richardson and Roumasset 1995). While the contracting cost is an income, the other costs are expenses incurred in completing the work. Thus, the subcontractor's profit model can be formulated as follows:

$$
\begin{gathered}
\Pi_{s}^{\mathrm{com}}=[c-C(a, p)-R(i, P)] q=\rho c q \\
C(a, P)=c_{\text {fixed }}+\frac{\alpha}{1+a} c_{\text {added }}\left(\frac{P}{1-P}\right) \\
R(i, P)=r\left(i_{0}+i\right)\left(\frac{1-P}{P}\right)
\end{gathered}
$$

where $C(a, P)=$ subcontractor's $\quad$ cost; $\quad c_{\text {fixed }}=$ fixed $\quad$ cost; $\alpha$ =proportion of labor work in the total subcontracted work; $c_{\text {added }}=$ cost of management effort; $R(i, P)=$ rework cost due to poor performance; $r=$ rework cost; $i_{0}=$ minimum inspection level; $i=$ inspection level; and $\rho=$ acceptable rate of profit for subcontractors.

\section{Subcontractor's Cost: \\ $C(a, P)=c_{\text {fixed }}+[\alpha /(1+a)] c_{\text {added }}[P /(1-P)]$}

$c_{\text {fixed }}$ is the fixed cost of performing the subcontracted work. If the subcontractor wants to improve work performance, additional resources, such as labor, should be input. As a result, performance is affected by the volume of additional resource input. According to the model of Richardson and Roumasset (1995), this kind of relationship between performance and additional resource input can be presented as a function $P=\mathrm{RI} /(\mathrm{RI}+1)$, where RI $=$ resource input. If the cost for additional resource input is defined as $c_{\text {added }}$, the additional cost to improve performance is $c_{\text {added }} \times \mathrm{RI}$, which can be converted to $c_{\text {added }} \times[P /(1-P)]$ using the above function. However, the additional cost can be reduced through coordination with the general contractor. Furthermore, because the general contractor's management tasks are limited to labor on site, the amount of the additional cost can be determined according to the parameter $\alpha$.

\section{Rework Cost due to Poor Performance: $R(i, P)=r\left(i_{0}+i\right)[(1-P) / P]$}

The proportion of rework required is determined by the subcontractor's performance and the level of inspection conducted by the general contractor. When the inspection level increases and performance is relatively poor, the proportion of rework increases. The parameter $r$ indicates the cost related to rework.

Accordingly, the profit function in the competitive model can be written as

$$
\begin{aligned}
\Pi_{G}^{\mathrm{com}}=\left[v-c-h\left(\frac{1-P}{P}\right)-\alpha m\left(i_{0}+i\right)-(1-s) k a\right] q \\
\Pi_{S}^{\mathrm{com}}=\left[p_{c}-c_{\text {fixed }}-\frac{\alpha}{1+a} c_{\text {added }}\left(\frac{P}{1-P}\right)-r\left(i_{0}+i\right)\left(\frac{1-P}{P}\right)\right] q \\
=\rho p_{c} q
\end{aligned}
$$

\section{Partnership Model}

The structure of the partnership model is similar to that of the competitive model. Nevertheless, the partnership model differs from the competitive model in the setup cost for establishing the partnership relationship and in the effectiveness of contractorsubcontractor coordination. The partnership model setup cost is the cost required for training, transferring technologies, and managerial support. Setup cost, which can result in switching cost, often prevents the general contractor from being able to easily change subcontractors for future projects. Consequently, the switching cost can affect the subcontractor's behavior. Also, of the two previous studies (Kim and Kim 2003; Zou and Lim 2005) that have asserted the need for more intimate and continuous relationships between contractors and subcontractors, both illustrate that such relationships can create communicable environments conducive to effective collaboration. However, the factors affecting the general contractor's profit are the same as those in the competitive model, excluding the existence of a setup cost, which is reflected in the partnership model in the equation below.

$$
\Pi_{G}^{\mathrm{part}}=\left[v-c-h\left(\frac{1-P}{P}\right)-\alpha m\left(i_{0}+i\right)-(1-s) k a\right] q-s_{1}
$$

where $s_{1}=$ setup cost.

\section{Model Application}

There are three variables in the models: $P$ (performance level of subcontractors), $a$ (coordination level), and $i$ (inspection level). To maximize profit, general contractors must select the appropriate $a$ and $i$ in both the competitive and partnership models (see 


\begin{tabular}{|c|c|}
\hline Competitive Model & Partnership Model \\
\hline $\begin{array}{l}\text { Step 1. Find the } P, a \text { and } i \text { necessary to } \\
\text { maximize the profit of the general contractor. }\end{array}$ & $\begin{array}{l}\text { Step 1. Find the } P \text { necessary to maximize } \\
\text { the profit of the subcontractor. }\end{array}$ \\
\hline$\frac{\partial}{\partial P} \prod_{G}^{c o m}(P, a, i)=0 \rightarrow P^{*}$ & $\frac{\partial}{\partial P} \prod_{S}^{p a r t}(P, a, i)=0 \rightarrow P^{s * *}$ \\
\hline$\frac{\partial}{\partial a} \prod_{G}^{c o m}(P, a, i)=0 \rightarrow a^{*}$ & $\begin{array}{l}\text { Step 2. Substitute } P * * \text { for } P \text { and determine } \\
\text { the } a * * \text { and } i * * \text { necessary to maximize the } \\
\text { general contractor's profit. }\end{array}$ \\
\hline$\frac{\partial}{\partial i} \prod_{G}^{c o m}(P, a, i)=0 \rightarrow i^{*}$ & \\
\hline & $\frac{\partial}{\partial i} \prod_{G}^{c o m}\left(P^{* *}, a, i\right)=0 \rightarrow \quad i^{* *}$ \\
\hline $\begin{array}{l}\text { Step 2. Determine the maximized profit function } \\
\text { by substituting } P^{*}, a^{*} \text { and } i^{*} \text { for } P \text {, } a \text { and } i \text {. } \\
\qquad \max \prod_{G}^{c o m}\left(P^{*}, a^{*}, i^{*}\right)\end{array}$ & $\begin{array}{l}\text { Step 3. Determine the maximized profit function } \\
\text { by substituting } P^{* * *}, a^{* *} \text { and } i^{* * *} \text { for } P, a \text { and } i . \\
\max \prod_{G}^{\text {part }}\left(P^{* * *}, a^{* *}, i^{* *}\right)\end{array}$ \\
\hline \multicolumn{2}{|c|}{+1} \\
\hline \multicolumn{2}{|c|}{$\begin{array}{l}\text { Parameters for Simulation } \\
\text { (Unless otherwise indicated, the parameters are set at their typical value) } \\
\text { 1. Shirking cost }(h) \text { and Rework cost }(r) \\
\text { 2. Degree of standardization }(s) \text { and Proportion of labor to the subcontracted work }(\alpha) \\
\text { 3. Coordination cost }(k) \text { and Shirking cost }(h)\end{array}$} \\
\hline \multicolumn{2}{|l|}{ Analysis of Simulation Results } \\
\hline \multicolumn{2}{|c|}{$\begin{array}{l}\text { If } \max \prod_{G}^{\text {comm }}\left(P^{*}, a^{*}, i^{*}\right)>\max \prod_{G}^{\text {part }}\left(P^{* *}, a^{* \prime}, i^{* \prime}\right) \text {, then competitive relationship is superior } \\
\text { If } \max \prod_{G}^{\text {com }}\left(P^{*}, a^{*}, i^{*}\right)<\max \prod_{G}^{\text {patr }}\left(P^{* *}, a^{* *}, i^{*}\right) \text {, then partnership relationship is superior }\end{array}$} \\
\hline
\end{tabular}

Fig. 2. Model application

"Step 1" of the competitive model and "Step 2" of the partnership model in Fig. 2). Meanwhile, the performance level is determined by the subcontractor. In each model, subcontractor performance level varies according to subcontractor behavior. Although the subcontractor can determine this performance level, in the competitive model, the subcontractor's behavior is controlled by the general contractor. So, it is assumed that the subcontractor should select the performance level to maximize the profit of the general contractor (see Step 1 of the competitive model in Fig. 2). On the other hand, in the partnership model, subcontractors can determine the performance level that will maximize their own profit (see Step 1 in Fig. 2). This is due to the switching costs that the general contractor would incur.
Based on these concepts, the detailed model solutions were determined and can be found in the Appendix. The model solutions in the Appendix are processes to maximize the profit functions $\Pi_{G}^{\mathrm{com}}(P, a, i)$ and $\Pi_{G}^{\mathrm{p} a r t}(P, a, i)$ by derivation of the functions. Then, $\max \Pi_{G}^{\text {com }}\left(P^{*}, a^{*}, i^{*}\right)$ and $\max \Pi_{G}^{\text {part }}\left(P^{* *}, a^{* *}, i^{* *}\right)$ are compared by simulating the models for variations of the parameters described in Table 2, and by finding the conditions under which each relationship yields maximized profits to the general contractor.

\section{Shirking Cost and Rework Cost}

A comparison of shirking and rework costs emphasizes how crucial it is that the general contractor select the most suitable contractor-subcontractor relationship type. A high shirking cost indicates that subcontracted work is a critical factor of profit. However, all forms of subcontracted work in a project do not carry equal importance. Work of longer duration, which requires more resources, has a greater impact on profit. Thus, as the importance of a work increases, the general contractor incurs additional costs due to poor subcontractor performance. Therefore, more important subcontracted work causes higher shirking costs.

Furthermore, if performance is poor, additional costs will be incurred to the subcontractor if it is determined by the general contractor's inspection that rework is required. Detecting problems during such inspections also incurs a controlling cost to the subcontractor. Thus, by using the shirking cost and the rework cost, the importance of subcontracted work to both general contractors and subcontractors can be determined and accounted for.

Considering the simulation results shown in Fig. 3, if the rework cost is higher than the shirking cost, the benefits of a partnership relationship surpass that of a competitive relationship. In the values of $r$ and $h$ on the line, the general contractor's profits under the two models become the same. However, whereas the competitive relationship is superior in the area above the line, the strategic partnership is superior in the area below the line.

This result suggests that "who" determines performance level is closely related to subcontracting type. In the partnership model, subcontractors can determine the performance level because doing so enables them to maximize profit. However, the general

Table 2. Values of Parameters

\begin{tabular}{|c|c|c|c|}
\hline \multicolumn{4}{|c|}{ Value of parameters } \\
\hline Parameter & Definition & Typical value & Range \\
\hline$h$ & Shirking cost of the general contractor & 1 & $0-1$ \\
\hline$k$ & Coordination cost & 1 & $0-1$ \\
\hline$\alpha$ & Proportion of labor work in the total subcontracted work & 0.5 & $0-1$ \\
\hline$s$ & Degree of standardization & 0.9 & $0-1$ \\
\hline$\rho$ & the rate of profit by subcontractor & 0.1 & $0-0.2$ \\
\hline$c_{\text {added }}$ & Labor costs for controlling performance by subcontractor & 1 & $0-5$ \\
\hline$q$ & Quantity & 100 & $100-500$ \\
\hline$n$ & Number of projects & 10 & \\
\hline$v$ & Value & 10 & \\
\hline$c$ & Unit cost & 1 & \\
\hline$c_{\text {fixed }}$ & Fixed cost by subcontractor & 50 & \\
\hline$r$ & Rework cost & 2 & \\
\hline$m$ & Inspection cost & 1 & \\
\hline$i_{0}$ & Minimum inspection level & 0.1 & \\
\hline$s_{1}$ & Set-up cost (investment, training, etc.) & 10 & \\
\hline
\end{tabular}




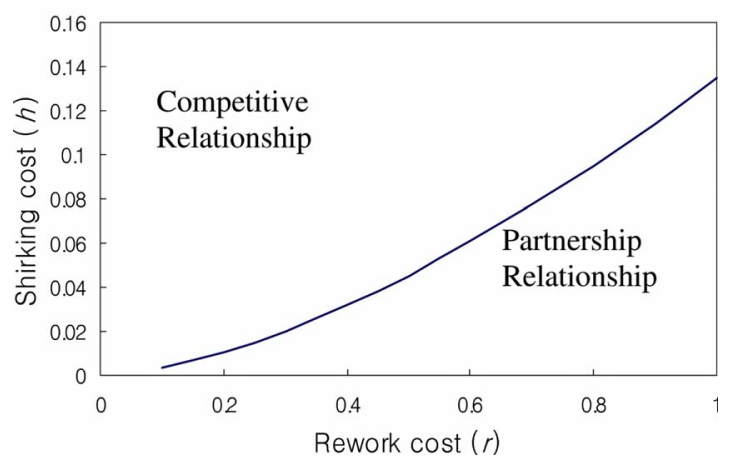

Fig. 3. Shirking cost and rework cost

contractor's managerial tasks are supposed to ensure an acceptable performance level because poor subcontractor performance incurs additional costs.

As well, when $r$ is high, the ramifications of poor subcontractor performance will be high; therefore, the subcontractor will tend to restrain opportunistic behavior that could result in performance problems. In this case, general contractors could reduce their total cost by minimizing or preventing poor subcontractor performance by coordinating with their subcontractor in a partnership relationship; thus, strategic partnerships are preferable in cases of higher $r$. However, when $r$ is low and $h$ is high, the general contractor cannot control the subcontractor's poor performance in a strategic partnership. In this case, the competitive relationship is superior because there is no switching cost; therefore, the general contractor can easily change their subcontractor when performance is unsatisfactory.

\section{Characteristics of Subcontracted Work and Relationship Type}

When construction firms attempt to decide whether or not to establish a partnership relationship with a subcontractor, one important factor is the type of subcontracted work. Because labor has a significant influence on transaction cost, one criterion used to classify subcontracted work is the proportion of labor to the total subcontracted work. As discussed earlier, whether the subcontracted work is standardized or customized also affects transaction costs.

In order to investigate the impact of the subcontracted work's characteristics on relationship type selection, the model was simulated for variations of $\alpha$ (proportion of labor work in the total subcontracted work) and $s$ (degree of standardization). As shown in Fig. 4, in the case of a low proportion of labor, the partnership relationship is superior to the competitive relationship, regardless of the degree of standardization. Normally, partnership requires intensive management efforts to prevent the subcontractor's opportunistic behavior. However, in the case of a low proportion of labor, the burden of inspection is comparatively lowered. In the same context, if the degree of standardization $(s)$ is constant, the benefits of a competitive relationship will surpass those of a partnership relationship as labor increases, and in turn, the general contractor will incur higher managerial costs for the subcontracted work. Thus, the more standardized the subcontracted work is, the more profitable the competitive relationship will be.

The degree of standardization also affects the coordination cost. If subcontracted work is highly standardized, coordinated

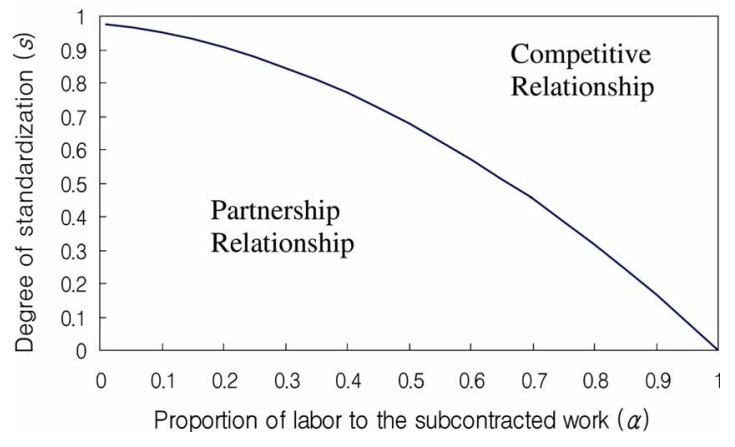

Fig. 4. Characteristics of the subcontracted work

activities between the general contractor and subcontractor become less complex. With regards to coordinative efforts, the simulation results show that the coordination level required to maximize the general contractor's profit in the partnership relationship is lower than in the competitive relationship. This indicates that general contractors can reap higher profits in the partnership relationship without having to manage high levels of coordination. Therefore, if the coordination cost decreases with a high degree of standardization, the influence of the coordination cost affecting the total cost is reduced. Henceforth, if subcontracted work is further standardized, the competitive relationship is a more desirable relationship than the partnership relationship. In addition, considering the influences of $\alpha$ and $s$ on general contractors' profits, lower values of $\alpha$ and $s$ indicate that a partnership relationship is favorable, whereas higher values of $\alpha$ and $s$ indicate that a competitive relationship is superior from the perspective of general contractors' profits.

\section{Coordination Cost and Rework Cost}

As general contractors are cost-sensitive, the coordination cost inevitably becomes an important factor in determining relationship type. The coordination cost also indicates the level of complexity of the subcontracted work. Coordinating with a subcontractor is not an easy task, especially if the subcontracted work entails significant variations. Variations can mean changes in design or specifications, frequent cost overruns, and even conflicts with other work. Coordinating subcontracted work that has more variations will require more time and will incur higher costs. The coordination cost affects the determination of performance level, coordination level, and inspection level. The way in which the coordination cost affects these variables can serve as a criterion for relationship type selection.

On the other hand, the rework cost is another parameter used in the simulations. In order to understand how the results differ according to the rework cost of the subcontractor work, the models were simulated for variations of the value $r$.

Overall, the results in Fig. 5 show that the partnership relationship is superior when the general contractor incurs a smaller shirking cost $(h)$. If the shirking cost is high, the subcontractor's poor performance results in a substantial reduction of the general contractor's profit. In the partnership relationship, when subcontractors attempt to maximize their own profit, they exhibit the tendency to perform at a less than optimal level. To prevent this, the general contractor increases the inspection level, which results in increased management costs. Consequently, transaction costs in 
Shirking cost and Coordination cost

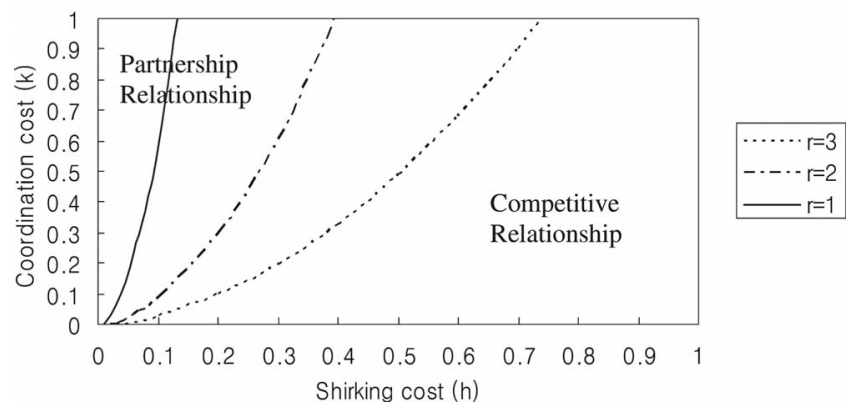

Fig. 5. Shirking cost and coordination cost of the general contractor

the partnership relationship become higher than in a competitive relationship. Thus, the competitive relationship is favorable when the shirking cost is high.

However, increasing the shirking cost of subcontractors $(r)$ ensures that their opportunistic behavior can be better controlled. This is because subcontractors are aware that poor performance can result in a decrease of their profits. Therefore, despite the high shirking costs general contractors might incur, the partnership relationship is clearly superior to the competitive relationship in this respect.

\section{Conclusions}

In this paper, two types of construction industry relationships between general contractors and subcontractors were discussed: competitive relationships and strategic partnerships. Based on the argument that construction firms should not use a one-size-fits-all approach for subcontractor management (Dyer et al. 1998), this study attempted to determine the conditions under which each relationship type is the most beneficial. The model of Richardson and Roumasset (1995) was adapted to the construction industry to develop two profit models for general contractors and subcontractors in both relationships. Then, these models were simulated for the parameter variations that affect the conditions and characteristics of subcontracted work, and the results were analyzed. Due to the difficulties involved in collecting actual data on transaction costs during construction (Constantino and Pietroforte 2002), in the examination of the relative fluctuations of transaction costs, relative values were focused on instead of the absolute values of the parameters. The simulation was conducted for: (1) the significance of subcontracted work to general contractors and subcontractors; (2) the characteristics of the subcontracted work; and (3) the costs affecting general contractors' transaction costs.

Consequently, the following practical guidelines for selecting the most appropriate relationship type were determined. First, it was found that the partnership relationship is superior to the competitive relationship only when general contractors incur a low shirking cost due to subcontractors' opportunistic behavior. This opportunistic behavior results from subcontractors' awareness that they will be less impacted by the negative consequences of poor performance than the general contractor. Therefore, even as the amount of shirking cost incurred by subcontractors increases, their opportunistic behavior can be controlled. Second, although general contractors can reduce transaction cost by establishing a partnership relationship for more customized work, the comparative advantages of the partnership relationship decrease as the proportion of labor increases. That is, the general contractor is required to put in more effort to manage subcontracted work in a partnership relationship than in a competitive relationship. Third, in a partnership relationship, the higher the coordination cost, the smaller the transaction cost incurred by the general contractor.

However, because this paper assumes hypothetical transactioncost-based conditions, the research results are limited in their applicability to real projects. Moreover, the assumptions are likely to emphasize the advantages of the competitive relationship and the disadvantages of the partnership relationship. As already noted, it is assumed that general contractors are able to choose the subcontractor's performance level in a competitive relationship but not in a partnership relationship. Considering the fact that general contractors generally prefer competitive contractorsubcontractor relationships, these assumptions are reasonable. Nevertheless, this article emphasizes that construction firms desiring closer relationships with subcontractors must understand the advantages and disadvantages of the different alternatives. As well, further in-depth analysis of contractor-subcontractor transactions is required to determine which relationship type is the most beneficial for both parties.

Although this paper's findings need to be further refined and validated through additional industry-based research, the transaction-cost-based profit models developed here can provide industry practitioners and researchers with new perspectives and valuable insights on contractor-subcontractor relationships. As well, if applied in actual construction projects, such knowledge could ultimately improve subcontracting practices.

\section{Acknowledgments}

This research was supported by a grant (Grant No. 05CIT-D0501) from Construction Technology Innovation funded by the Ministry of Construction and Transportation of Korea.

\section{Appendix. Model Solutions}

To reflect the different behaviors of the general contractor and the subcontractor, the general contractor, according to the competitive model, chooses the variables $P, a$, and $i$ to maximize profit. However, in the partnership model, the performance level $P$ is determined by the subcontractor, not by the general contractor.

\section{Competitive Model}

$$
\max \Pi_{G}^{\mathrm{com}}=\left[v-c-h\left(\frac{1-P}{P}\right)-\alpha m\left(i_{0}+i\right)-(1-s) k a\right] q
$$

$$
\begin{aligned}
\Pi_{S}^{\text {com }} & =\left[c-c_{\text {fixed }}-\frac{\alpha}{1+a} c_{\text {added }}\left(\frac{P}{1-P}\right)-r\left(i_{0}+i\right)\left(\frac{1-P}{P}\right)\right] q \\
& =\rho p_{c} q
\end{aligned}
$$

Substituting $c$ into Eq. (10) from Eq. (11), and considering the derivatives $\left(\partial / \partial P \Pi_{G}^{\text {com }}=0, \partial / \partial a \Pi_{G}^{\text {com }}=0\right.$, and $\left.\partial / \partial i \Pi_{G}^{\text {com }}=0\right)$, we can find the $P, a$, and $i$ necessary to maximize the profit of the general contractor. 


$$
\begin{gathered}
P^{*}=\frac{1}{\frac{\alpha c_{\text {added }}}{(1-\rho)(1-s) k(1+a)^{2}}+1}\left(a=a^{*}\right) \\
a^{*}=\left\{\frac{\alpha c_{\text {added }}\left[h-\frac{r\left(i_{0}+i\right)}{1-\rho}\right]}{(1-\rho)(1-s)^{2} k^{2}}\right\}-1 \\
i^{*}=0
\end{gathered}
$$

\section{Partnership Model}

$$
\begin{aligned}
\Pi_{G}^{\mathrm{part}} & =\left[v-c-h\left(\frac{1-P}{P}\right)-\alpha m\left(i_{0}+i\right)-(1-s) k a\right] q-s_{1} \\
\max \Pi_{S}^{\text {part }} & =\left[c-c_{\text {part }}-\frac{\alpha}{1+a} c_{\text {added }}\left(\frac{P}{1-P}\right)-r\left(i_{0}+i\right)\left(\frac{1-P}{P}\right)\right] q \\
& =\rho p_{c} q
\end{aligned}
$$

The subcontractor can choose the performance Level $P$ to maximize the subcontractor's profit. Considering the derivative $\left(\partial / \partial P \Pi_{S}^{\text {part }}=0\right)$ in Eq. (13), we have

$$
P^{* *}=\frac{1}{\left[\frac{\alpha c_{\text {added }}}{(1+a) r\left(i_{0}+i\right)}\right]^{1 / 2}+1}
$$

However, because the coordination level and the inspection level can be chosen by the general contractor, we can determine the $a^{* *}$ and $i^{* *}$ necessary to maximize the general contractor's profit. Substituting $P^{* *}$ for $P$ in Eq. (12) and considering the derivatives $\left(\partial / \partial a \Pi_{G}^{\text {part }}=0\right.$ and $\left.\partial / \partial i \Pi_{G}^{\text {part }}=0\right)$, we find the $a^{* *}$ and $i^{* *}$ as

$$
\begin{gathered}
a^{* *}=\left[\frac{h^{2} \alpha^{2} m c_{\text {added }}}{4 r(1-s)^{3} k^{3}}\right]^{1 / 4}-1 \\
i^{* *}=\left[\frac{h^{2} c_{\text {added }}(1-s) k}{4 r \alpha^{2} m^{3}}\right]^{1 / 4}-i_{0}
\end{gathered}
$$

\section{References}

Bensaou, M. (1999). "Portfolios of buyer-supplier relationships." Sloan Manage. Rev., 40(4), 35-43.

Costantino, N., and Pietroforte, R. (2002). "Subcontracting practices in USA homebuilding-An empirical verification of Eccles's findings 20 years later." European Journal of Purchasing \& Supply Management, $8,15-23$.

Dainty, A. R. J., Briscoe, G. H., and Millett, S. J. (2001). "Subcontractor perspectives on supply chain alliance." Constr. Manage. Econom., 19(8), 841-848.

Dyer, J. H., Cho, D. S., and Chu, W. (1998). "Strategic supplier segmentation: The next 'big practice' in supply chain management." California Manage. Rev., 40(2), 57-77.

Hinze, J., and Tracy, A. (1994). "The Contractor-subcontractor relationship: The subcontractor's view." J. Constr. Eng. Manage., 120(2), 274-287.

Kale, S., and Arditi, D. (2001). "General contractors' relationships with subcontractors: A strategic asset." Constr. Manage. Econom., 19, 541-549.

Kim, J. H., and Kim, H. S. (2003). "Partnering strategy for general contractors with reinforced concrete sub-contractors." Journal of the Architectural Institute of Korea, 19(8), 129-136.

Kumaraswamy, M. M., and Matthews, J. D. (2000). "Improved subcontractor selection employing partnering principles." J. Manage. Eng., 16(3), 47-57.

Latham, M. (1994). Construction the team, Her Majesty's Stationery Office, London.

Pint, E. M., and Baldwin, L. H. (1997). "Strategic sourcing-Theory and evidence from economics and business management." RAND Monograph Rep., The Rand Corporation, Santa Monica, Calif.

Richardson, J., and Roumasset, J. (1995). "Sole sourcing, competitive sourcing, parallel souring: Mechanisms for supplier performance." Manage. Dec. Econ., 16, 71-84.

Shimizu, J. Y., and Cardoso, F. F. (2002). "Subcontracting and cooperation network in building construction: A literature review." Proc., IGLC-10, International Group for Lean Construction, Grramado, Brazil.

Trent, R. J. (2005). "Why relationships matter." Supply Chain Manage. Rev., 9(8), 53-59.

Usdiken, B., Sozen, Z., and Enbiyaoglu, H. (1988). "Strategies and boundaries: Subcontracting in construction." Strategic Manage. J., 9(6), 633-637.

Williamson, O. E. (1989). "Transaction cost economics." Handbook of industrial organization, R. Schmalensee and R. D. Willig, eds., Vol. 1,. Elsevier Science, New York.

Zou, P. X. W., and Lim, T. H. (2005). "Developing main contractorsubcontractor long-term relationships: Current practice and strategies." Third Int. Conf. on Construction in the 21st Century, Construction in the 21st Century, Athens. 